\title{
Making Modern Social Science: The Global Imagination in East Central and Southeastern Europe after Versailles
}

\author{
Katherine Lebow* ${ }^{\star}$ Małgorzata Mazurek and Joanna Wawrzyniak \\ *katherine.lebow@chch.ox.ac.uk
}

The events of 1914 initiated the redrawing of many boundaries, both geopolitical and intellectual. At the outbreak of the war the London-based anthropologist Bronisław Malinowski was at a professional meeting in Australia. Technically an 'enemy alien' (a Pole of AustroHungarian citizenship), he was barred from returning to Britain; stranded in Australia, under surveillance by authorities and with insecure finances, Malinowski began fieldwork in the Trobriand Islands that would result in his groundbreaking Argonauts of the Western Pacific (1922). ${ }^{1}$ Argonauts' influence rested on its compelling portrait of the anthropologist as 'participant-observer', the insider/outsider uniquely poised to decode and recode cultures and meanings. ${ }^{2}$ Malinowski thus adeptly retooled his own ambiguous status into a paradigm of the ethnographer's optimal subject-position - quipping that he himself was particularly suited to this role, as 'the Slavonic nature is more plastic and more naturally savage than that of Western Europeans'. 3

While Malinowski was catalysing disciplinary change in the Western Pacific, his co-national Florian Znaniecki was transforming sociology in the American Midwest. By war's end Znaniecki had co-authored the Chicago school of sociology's seminal work, The Polish Peasant in Europe and America (with William I. Thomas, 1918-20). ${ }^{4}$ Unlike Malinowski Znaniecki then returned to Poland, establishing sociology as a recognised discipline in the new state. While the Sociology Institute in Poznań served as an engine of transatlantic exchange throughout the 1920s and 1930s, sociological concepts also made it possible to imagine Polish society in a global context. Suddenly, it seemed just as plausible to consider Warsaw in relation to New York or Chicago as to Prague, Budapest or Zagreb.

This issue builds on workshops held at the Heyman Center for the Humanities at Columbia University ('Malinowski's Children: East Central European "Betweenness" and Twentieth Century Social Science') and the Institut für Ost- und Südeuropaforschung Regensburg ('Epistemologies of In-Betweenness: East Central Europe and the World History of Social Science, 1890-1945'). The editors are grateful for the generous support and assistance of Mark Mazower, Alan Timberlake and Sarah Monks at Columbia and Ulf Brunnbauer in Regensburg. Many thanks, too, to commentators and discussants Tal Arbel, Deborah Coen, David Engerman, Manu Goswami, Claudia Kraft, Jan Surman, Maria Todorova, Balázs Trencsényi and Andrew Zimmerman, to all participants of the two workshops and to Marta Bucholc, Ned Lebow and the editors and reviewers of Contemporary European History for their insightful contributions and support.

1 Michael Young stresses the serendipity involved in Malinowski's decision to begin fieldwork in the Trobriands in 'The Intensive Study of a Restricted Area, or, Why Did Malinowski Go to the Trobriand Islands?', Oceania, 55, 1 (1984), 1-26.

${ }^{2}$ In the words of James Clifford, 'ethnography is actively situated between powerful systems of meaning. It poses its questions at the boundaries of civilisations, cultures, classes, races and genders. Ethnography decodes and recodes, telling the grounds of collective order and diversity, inclusion and exclusion.' 'Introduction: Partial Truths', in Clifford and George E. Marcus, eds., Writing Culture: The Poetics and Politics of Ethnography (Berkeley: University of California Press, 1986), 2-3.

3 Bronisław Malinowski, Argonauts of the Western Pacific (London: Routledge, 2014 [1922]), 21. On 'intermediation' see Kapil Raj, 'Go-Betweens, Travelers, and Cultural Translators', in Bernard Lightman, ed., A Companion to the History of Science (Chichester, UK: John Wiley \& Sons, 2016), 39-57.

4 William I. Thomas and Florian Znaniecki, The Polish Peasant in Europe and America (New York: Dover Publications, 1958 [1918-20]).

() Cambridge University Press 2018. 
Malinowski's creative appropriation of his liminal status, on the one hand, and Znaniecki's assertion of East European and North American commensurability, on the other, point to the new era of epistemic experimentation that is the subject of this special issue, and that accompanied political reconfigurations of the non-Western world beginning in the late nineteenth century. The disproportionate role of scholars from Central/Eastern/Southeastern Europe in twentieth-century social science has been oft noted but little explained. We propose that the geopolitical shift from a world of empires to one of nation states, which started in the Balkans and East Central Europe, and continued later in dependent and colonial territories, recharged social science as a field of potential innovation and transformation. As millions in the region changed their places of residence and/or citizenship, the quest to reinvent knowledge about what binds people and what divides them, what is close by and what is distant, what is backward and what is modern, what is a part and what is the whole, was particularly rich and historically momentous.

The modern social and human sciences played a pivotal role in this process, and, as this issue argues, East Central and Southeastern Europe served as a key locality from which to view the world through new epistemological lenses. ${ }^{5}$ Historians of science typically use the term 'locality' to denote a site of contact and circulation between local and cosmopolitan epistemic cultures; here we also wish to suggest a conceptual space that, while ostensibly identified with a particular geographical area, allowed social scientists to project particular scientific problems onto a universal plane. In taking this approach, the issue points to fundamental questions about how regions deemed 'peripheral' participate in the production of global scholarly knowledge. ${ }^{6}$ The entangled transnational practices it describes suggest that the history of modern social science can and should be narrated beyond canons, geopolitical hierarchies and centre-periphery

\footnotetext{
5 The history of science, as distinct from intellectual history, took a 'geographic turn' in the mid-1980s. See, for example, David Wade Chambers and Richard Gillespie, 'Locality in the History of Science: Colonial Science, Technoscience, and Indigenous Knowledge', Osiris, $2^{\text {nd }}$ series, 15 (2000), 221-40; Carla Nappi, 'The Global and Beyond: Adventures in the Local Historiographies of Science', Isis, 104, 1 (2013), 102-10; Manolis Patiniotis, 'Between the Local and the Global: History of Science in the European Periphery Meets Post-Colonial Studies', Centaurus, 55, 4 (2013), 361-84; Steven Shapin, 'Placing the View From Nowhere: Historical and Sociological Problems in the Location of Science', Transactions of the Institute of British Geographers, 23, 1 (1998), 5-12. Intellectual history has more recently begun to address the spatial dimension through its engagement with global and transnational history. See Samuel Moyn and Andrew Sartori, eds., Global Intellectual History (New York: Columbia University Press, 2013); Wiebke Keim, Ercüment Çelik and Veronika Wöhrer, Global Knowledge Production in the Social Sciences: Made in Circulation (London: Routledge, 2016); Michael Lang, 'Histories of Globalization(s)', in Prasenjit Duara, Viren Murthy and Andrew Sartori, eds., A Companion to Global Historical Thought (Malden, MA: John Wiley \& Sons, 2014), 399-411; Kapil Raj and H. Otto Sibum, eds., Histoire des sciences et des savoirs, Vol. 2, Modernité et globalisation (Paris: Éditions du Seuil, 2015). See also Davide Rodogno, Bernhard Struck and Jakob Vogel, Shaping the Transnational Sphere: Experts, Networks and Issues from the 1840s to the 1930s (New York: Berghahn, 2015); Pierre-Yves Saunier, Transnational History (Houndmills, Basingstoke, Hampshire: Palgrave Macmillan, 2013); Johan Heilbron, Nicolas Guilhot and Laurent Jeanpierre, 'Toward a Transnational History of the Social Sciences', Journal of the History of the Behavioral Sciences, 44, 2 (Spring 2008), 146-60.

${ }^{6}$ In this sense, our approach is distinct from one focusing on the development of the social sciences in East Central and Southeastern Europe. Such attempts at writing the histories of social scientific disciplines within discrete national frameworks began, in fact, quite soon after their institutionalisation (a useful overview of several national canons is offered by Max Kaase, Vera Sparschuh and Agnieszka Wenninger, eds., Three Social Science Disciplines in Central and Eastern Europe: Handbook on Economics, Political Science and Sociology (1989-2001) [Berlin: GESIS/ Social Science Information Centre, 2002], http://nbn-resolving.de/urn:nbn:de:0168- ssoar-278699 [last visited 4 Feb. 2017]). Attempts to rewrite the history of East Central and Southeastern European sciences and ideas from a transnational perspective have only just begun. So far, their most comprehensive result is Balázs Trencsényi, Maciej Janowski, Mónika Baár, Maria Falina and Michal Kopeček, A History of Modern Political Thought in East Central Europe, Vol. I: Negotiating Modernity in the 'Long Nineteenth Century' (Oxford: Oxford University Press, 2016); Vol. II, forthcoming. See also Roumen Daskalov and Diana Mishkova, eds. Entangled Histories of the Balkans, Vol. II: Transfers of Political Ideologies and Institutions (Leiden: Brill, 2014). These works challenge European intellectual canons not only by uncovering names and ideas unfamiliar to an international readership but also by proposing new chronologies and categories for a regional history of political ideas in a pan-European context.
} 
frameworks; this history can, indeed, be told from any place where people have reimagined their relationship to a shared global modernity. ${ }^{7}$

After Versailles the new nation states in this part of Europe were both the subjects and objects of knowledge production. On the one hand, they became a testing ground for various ideologies and technologies of scientific engineering originating in Western Europe, the United States and/ or the Soviet Union. These interventions heavily influenced processes of state building in the region and were later used as models for developmental politics in other parts of the world. ${ }^{8}$ On the other hand, scholars in and from the region actively contributed to new social scientific concepts and systems, constructing a global imaginary in which to position themselves following the collapse of the continental European empires. ${ }^{9}$ Crucial to these political and epistemic reinventions was the making of a new scalar imagination, which Deborah Coen aptly describes as a process of 'situating the known world in relation to times or places that are distant or otherwise inaccessible to direct experience'. ${ }^{10}$

The region's historic liminality as a putative bridge between 'Occident' and 'Orient' profoundly shaped these processes. ${ }^{11}$ The creation of East Central and Southeastern Europe as a distinct geopolitical entity after Versailles only heightened the paradoxes of liminality, literally inscribing its 'betweenness' in territorial arrangements of a cordon sanitaire between Soviet Russia and the West. ${ }^{12}$ Although deemed worthy of 'national self-determination', the new peoples of Europe commanded an ambiguous status vis-à-vis Europe's great colonial powers, who so conspicuously denied these rights to their own imperial subjects. Experts, meanwhile, grouped the region with Asia and Africa as one of the world's impoverished agrarian zones, while travellers, including some Western social scientists, came as they had since early modern times to marvel at this more savage, unspoiled and authentic 'other' Europe. ${ }^{13}$

For scholars from this part of Europe the result was a quest for self-knowledge in which 'betweenness' functioned not just as an other imposed optic but also as an epistemic resource for positioning the region on the map of human and social science. Social science, with its pursuit of universal scales and categories of comparison, became particularly fertile ground for such endeavours. As the essays here show, some scholars parlayed the region's ambiguous position on an imagined civilisational and developmental gradient into ambitious methodological and theoretical

7 Carol Gluck, 'The End of Everywhere: Writing Modernity Now', in American Historical Review, 116, 3, (2011), 676-87.

8 Mark Mazower, Governing the World: The History of an Idea, 1815 to the Present (New York: Penguin Books, 2013); Corinna Unger, Ostforschung in Westdeutschland (Stuttgart: Franz Steiner Verlag, 2007); James Mark, Steffi Marung and Artemy M. Kalinovsky, eds., Alternative Globalizations: Eastern Europe and the Decolonizing World (Bloomington, IN: University of Illinois Press), forthcoming.

9 Włodzimierz Borodziej, Stanislav Holubec and Joachim von Puttkamer, eds., Mastery and Lost Illusions, Space and Time in the Modernization of Eastern and Central Europe (Oldenbourg: de Gruyter, 2014); Steven Seegel, Map Men: Transnational Lives and Deaths of Geographers in the Making of East Central Europe (Chicago: University of Chicago Press, 2018).

10 Deborah R. Coen, 'Big is a Thing of the Past: Climate Change and Methodology in the History of Ideas', Journal of the History of Ideas, 77, 2 (2016), 312.

11 On political geography, see Alan Dingsdale, Mapping Modernities: Geographies of Central and Eastern Europe, 1920-2000 (London: Routledge, 2002); Dietmar Müller, 'Geschichtsregionen und Phantomgrenzen', in Béatrice von Hirschhausen et al., eds., Phantomgrenzen. Räume und Akteure in der Zeit neu denken (Göttingen: Wallstein Verlag, 2015), 57-83; Roumen Daskalov, Diana Mishkova, Tchavdar Marinov and Alexander Vezenkov, eds., Entangled Histories of the Balkans, Vol. IV: Concepts, Approaches, and (Self-)Representations (Leiden: Brill, 2017). On the geopolitical aspects of Central and Eastern European expertise in the Cold War see, for example, Martha Lampland, 'The Technopolitical Lineage of State Planning in Hungary, 1930-1956', in Gabrielle Hecht, ed., Entangled Geographies: Empire and Technopolitics in the Global Cold War (Cambridge, MA: MIT Press, 2011), 1-29.

12 Mark Mazower, Dark Continent: Europe's Twentieth Century (New York: Alfred A. Knopf, 1999), 42.

13 Sunil Amrith and Patricia Clavin, 'Feeding the World: Connecting Europe and Asia, 1930-1945', Past and Present, Supplement 8 (2013), 29-50; Patricia Clavin, Securing the World Economy: The Reinvention of the League of Nations, 1920-1946 (Oxford: Oxford University Press, 2013); Larry Wolff, Inventing Eastern Europe: The Map of Civilization on the Mind of the Enlightenment (Stanford: Stanford University Press, 1994). 
agendas linking 'West' and 'East', 'civilised' and 'savage' or 'first' and 'third' worlds. Others, echoing scholars of the Habsburg Monarchy, projected the region as a 'globe in miniature' ideal for testing and developing new world-scale concepts and categories. ${ }^{14}$ For others, tensions between the universalities of race and civilisation and the specificities of geography, history and culture prompted the search for new epistemological foundations for social science as a whole.

It bears emphasising that the social scientists considered here took the 'social' in 'social science' seriously. In this respect this issue diverges from a small but growing literature on social science in interwar East Central and Southeastern Europe that foregrounds the instrumentalisation of expert knowledge by states and international organisations and the turn to scientistic paradigms such as race. ${ }^{15}$ Instead, we focus on social scientists' roles in wide-ranging debates, at both the national and transnational levels, over the meaning of concepts like nationality, religion, rurality or class. This was a search to define the 'social' itself - and also, in many cases, to identify the conditions for its emancipation. By contrast to the generally liberal emigré social scientists whose work is better known in the West, a number of these scholars held left-wing commitments to socialism, agrarian populism or Marxism. As the milieux in which these debates took place were ravaged by the Second World War and Stalinisation, and positivist and scientistic models came to dominate global social science, these debates themselves were often lost to historical view.

In a region and period marked by dramatic ruptures and discontinuities, biography can be a particularly useful tool for uncovering scientific histories against the grain. The articles here therefore present a number of fascinating and under-explored intellectual biographies in the fields of economics, statistics, sociology, social medicine and psychiatry. In bringing to light the personal dimensions of scientific exchange and innovation, they show how transnational intellectual entanglements worked in practice between Warsaw and Paris, Kraków and New York, Polesie and Jamaica or Belgrade and Conakry. Focusing, moreover, not just on successes but on 'dead ends' and paths not taken, they offer clues to the dynamics of inclusion and exclusion that continue to shape histories of the field.

If this issue takes one geopolitical reconfiguration as its starting point, another brings it to a close. The Second World War and the Cold War were unparalleled catastrophes for the academics of East Central and Southeastern Europe. Those lucky enough to survive war and genocide into the post-war era found, at best, their scholarly networks crudely bisected by the Iron Curtain. And yet it was at this moment, marked by the universal extension of the principle of self-determination and the birth of a new 'era of development', that many of their social scientific innovations - sometimes under the guise of state socialism - finally 'went global'. The last part of the issue therefore carries us forward into the post-war period, considering some of the ambiguous afterlives of figures and ideas incubated in the age of Versailles, 'little dictators' and global economic crisis.

'Making Modern Social Science' deals with scholars who, in the first half of the twentieth century, used the heterogeneity of social life in their region as a template for conceptualising the world and their countries' place within a global framework. With this in mind, the issue's first two essays shed light on the regional origins of a spatial imagination in economics and statistics. Quinn Slobodian indicates in his contribution that practices of 'scaling up' local circumstances in

\footnotetext{
14 See Deborah Coen, Climate in Motion: Science, Empire and the Problem of Scale (Chicago: Chicago University Press, 2018); Pieter Judson, The Habsburg Empire: A New History (Cambridge, MA: Harvard University Press, 2016), 327-8.

15 On recent efforts to historicise the relationship between science and nation states see, for example, the special issue of Acta Poloniae Historica, 'Social Science and Politics in Early 20th Century East-Central Europe' (2017), 114; on expert cultures, Martin Kohlrausch, Katrin Steffen and Stefan Wiederkehr, eds., Expert Cultures in Central Eastern Europe. The Internationalization of Knowledge and the Transformation of Nation States since World War I (Osnabrück: fibre Verlag, 2010); on biopolitics/race science, Marius Turda and Paul J. Weindling, eds., Blood and Homeland: Eugenics and Racial Nationalism in Central and Southeast Europe, 1900-1940 (Budapest: CEU, 2007); Christian Promitzer, Sevasti Trubeta and Marius Turda, eds., Health, Hygiene and Eugenics in Southeastern Europe to 1945 (Budapest: CEU, 2011); Maciej Górny, Wielka Wojna profesorów. Nauki o człowieku (1912-1923) (Warsaw: Instytut Historii PAN, 2014).
} 
Central and Eastern Europe to the global level were already present in the Habsburg empire. Slobodian looks at Lviv-born, Vienna-educated Ludwig von Mises, who used an imaginary Austro-Hungary - with its internal division of labour and allegedly harmonious liberal economic order - as a reference for his (neo)liberalism.

'World scale' remained an important device of political and scholarly claim making after the collapse of the Central and Eastern European empires. Małgorzata Mazurek deals with Ludwik Landau's World Economy, a reaction to the liberal orthodoxy of the 1920s and early 1930s, and in particular, to statistical practices that neglected rural and colonial world regions. Landau's radical revision of international statistics by means of a highly original Marxist approach represented Poland (and more broadly, Southern and Eastern Europe) as a geo-economic unit that shared features of both the Western and non-Western worlds. Landau thereby challenged well-established claims about the statistical incommensurability of 'civilised', 'colonial' and/or non-industrialised territories, introducing universal scale into the field of international statistics.

The next two essays focus on the transnational circulation of two key social scientific paradigms of the early twentieth century - those of Émile Durkheim and Bronisław Malinowski, respectively - within and beyond East Central Europe. In an era of sudden social dislocation, Durkheim and Malinowski proposed universal methods for the study of world societies. Joanna Wawrzyniak, writing on the only non-French member of the Durkheimian inner circle, the Pole Stefan Czarnowski, highlights how the central Durkheimian question of the mechanisms of social integration found its East Central European subtext with regard to nation and labour. After publishing a first monograph in Paris on the role of religion, heroes and the reinvented past in nation building, Czarnowski returned to Poland where, confronting local manifestations of the global political and economic crisis in the 1930s, he formulated a labour centred, comparative historical sociology of culture and developed cases studies on the European working class, the Polish peasantry and colonial Central Africa. In addition, Wawrzyniak points us beyond assumptions of the unidirectional transfer of ideas from metropole to periphery, showing how entanglements such as Czarnowski's influence on James Joyce have remained invisible in European intellectual history.

Katherine Lebow's contribution points to East Central Europe as a locality 'on the move', following the intersecting paths of two of Bronisław Malinowski's Polish protégés, Feliks Gross and Józef Obrębski, into New World exile after the Second World War. Lebow describes a methodology and body of knowledge with a transcontinental trajectory and famous pedigree that nonetheless ended up at the margins of Cold War science. In their research on rural Jamaica or the Arapaho reservation, Obrębski and Gross saw a chance to 'go global' with pre-war Polish intellectual agendas, including what Obrębski, in response to decolonisation, called the 'sociology of rising nations'. US social science, however, was not receptive to methods and ideas prefiguring post-colonial and constructivist trends that would emerge only a generation later.

The issue's last three articles present three crucial and specific aspects of regional social knowledge in global entanglements: rurality, social medicine and psychiatry. Raluca Muşat describes how Dimitrie Gusti successfully established rural sociology as the Romanian 'national science', positioning it within the rising field of international peasant studies and transforming it into a powerful, internationally recognised scholarly enterprise before it fell into oblivion under communism. Muşat shows that Romanian rural sociology found wide resonance among Western liberals and international experts, meeting a growing demand for expert knowledge about poor rural populations. Gusti was among several regional scholars who successfully contributed to the development of transcontinental expertise about rural life in the non-Western world during the pioneering years of international development.

Sara Silverstein shows how, like Gusti, the Yugoslav scholar Andrija Štampar introduced ideas about rural hygiene and social medicine to an international audience. With the backing of the Rockefeller Foundation and the League of Nations, Štampar successfully developed and implemented projects which were initially aimed at 'backward' agrarian communities in the Balkans, 
China and Latin America. The story of Štampar's initiatives, according to Silverstein, complicates historiographical narratives equating interwar ideas of social medicine with eugenics and social control.

Finally, Ana Antic offers us a glimpse of a post-war encounter between the so-called 'second' and 'third' worlds. Showing how post-colonial Guinea became a testing ground for Yugoslav psychiatrists combining lessons from interwar and wartime Europe, Marxism and Yugoslav theories of the 'revolutionary self, Antic's study recapitulates many problems and themes raised in the issue's other contributions. The outcome of this encounter - an anti-colonial psychiatry that preserved some assumptions of European colonial knowledge - sheds new light on the history of European social science in a post-colonial setting.

To conclude, this issue attempts to contextualise a key moment in intellectual history with regard to the historical experiences of a particular time and place. More broadly, by considering East Central and Southeastern Europe as a node in the creation, translation and transformation of global social scientific knowledge, it addresses the transnational circulation of people and ideas, revisits the stakes and stakeholders in key social scientific methodological and epistemological debates and explores dead ends, paths not taken and repressed or forgotten disciplinary histories. It seeks to destabilise scientific dichotomies of East and West, North and South, coloniser and colonised, European and Other. Given our current scepticism toward social scientific claims of universal truth, this seems a timely endeavour; as the essays here remind us, the social sciences have always been part of the very 'processes of innovation and structuration' they claim to illuminate. ${ }^{16}$ And yet for this same reason, we should neither caricature nor underestimate the attraction of social science for so many intellectuals in the first half of the twentieth century nor their efforts to use it both to understand the world and to change it.

\footnotetext{
Cite this article: Lebow, K., Mazurek, M. and Wawrzyniak, J. 2019. Making Modern Social Science: The Global Imagination in East Central and Southeastern Europe after Versailles. Contemporary European History 28: 137-142, doi:10.1017/ S0960777318000474
}

${ }^{16}$ James Clifford, 'Introduction: Partial Truths', in Clifford and Marcus, Writing Culture, 2-3. 